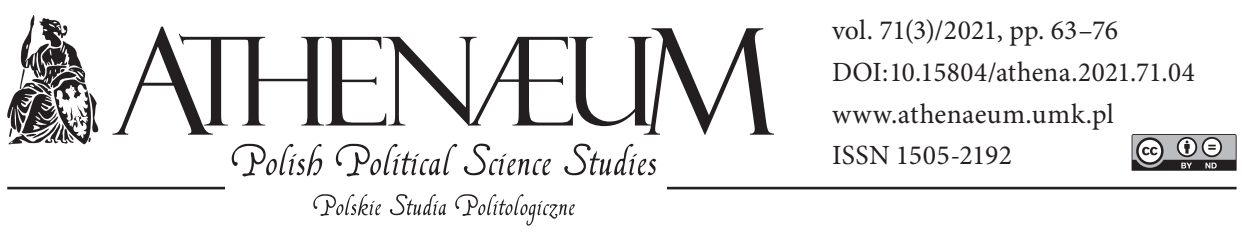

\title{
STATE POLICY TOWARDS LABOUR MARKET CHANGES CAUSED BY COVID-19
}

\author{
POLITYKA PAŃSTWA WOBEC ZMIAN NA RYNKU PRACY \\ SPOWODOWANYCH COVID-19
}

Magdalena Mikołajczyk* 웅

\begin{abstract}
- ABSTRACT
The aim of the paper is to present strategies for minimising negative effects of the crisis caused by COVID- 19 by state authorities of non-European countries in the first months after the announcement of the pandemic. The focus is on employment and labour market policy instruments. The research is comparative in its nature and was conducted using the desk research and discourse analysis methods. The source/unit in the analysis were the rapid assessments of the employment impacts of COVID-19 submitted to the International Labour Organisation. The study did not cover European Union Member States. Among the instruments and countermeasures typical of employment and labour market policies, few innovative solutions were identified, tailored to local specifics and taking into account the effects of the pandemic - the ecological crisis and the emergence of technological unemployment. The results achieved implicate a number of further questions relevant for public policy research. Research shows that COVID-19 contributes to
\end{abstract}

Celem artykułu jest zaprezentowanie strategii minimalizowania negatywnych skutków kryzysu spowodowanych przez COVID-19 przez władze państwowe w pierwszych miesiącach od ogłoszenia pandemii. Koncentrowano uwagę na instrumentach polityki zatrudnienia i rynku pracy. Badania miały charakter porównawczy, prowadzone były metodami desk research oraz analizy dyskursu. Źródłem/jednostką w badaniu były bieżące analizy wpływu COVID-19 na zatrudnienie składane w Międzynarodowej Organizacji Pracy. Nie objęto badaniem państw należących do Unii Europejskiej. Wśród instrumentów i środków zaradczych typowych dla polityki zatrudnienia i polityki rynku pracy wykazano nieliczne rozwiązania innowacyjne, dostosowane do specyfiki lokalnej oraz uwzględniające skutki problemów nieunieważnionych przez pandemię - kryzysu ekologicznego oraz kwestii związanej z pojawianiem się bezrobocia technologicznego. Osiągnięte rezultaty rzutują na szereg dalszych pytań właściwych do posta-

* Pedagogical University of Kraków, Institute of Political Science. 
deepening of the polarisation of society and existing labour market policy instruments in countries will not be sufficient to stop social exclusion due to unemployment especially in countries with a predominantly informal economy. Meanwhile, a category of people has emerged, due to the suspension of business activities and internal migration, whose status is also "suspended" (liminal) between work and unemployment. wienia w badaniach polityki publicznej. Badania pokazują, że COVID-19 przyczynia się do pogłębiania polaryzacji społeczeństwa, a istniejące w poszczególnych krajach instrumenty polityki rynku pracy nie wystarczą, by powstrzymać wykluczenie społeczne $\mathrm{z}$ powodu bezrobocia, zwłaszcza w krajach o dominującej gospodarce nieformalnej. Tymczasem ze względu na zawieszanie działalności gospodarczej i brak możliwości reemigracji pojawiła się nowa kategoria osób, których status liminalny oznacza „zawieszenie” między pracą a bezrobociem.

Słowa kluczowe: COVID-19; kryzys; rynek pracy; polityka zatrudnienia; instrumenty poli-

tyki rynku pracy
Keywords: COVID-19; crisis; labour market; employment policy; labour market policy instruments

\section{INTRODUCTION}

Not only observations, but also the analysis of scientific discourse, where COVID-19 (SARS-Cov-2) is one of the key words, show that authors associate the pandemic with a catastrophe, crisis, tsunami, collapse, a shock affecting all states and their citizens and various subsystems of the global system. Also present in the discourse is the metaphor of Nassim Nicholas Taleb calling such events "black swans" (Taleb, 2010). It should be added that the assessments formulated in the introductions to these studies emphasise that it is an effect and - which is obvious to social science researchers - a cause of the processes whose course is not predictable. It should also be mentioned that the subject of the research is to focus the activities of international organisations, governments, administrations at various levels and all public services on minimising the negative consequences of the pandemic in various areas of social life and economic sectors. The strategies and instruments are examined, mainly in relation to those used so far in local or regional employment policies, but it is too early to assess their effectiveness.

However, the appearance of the virus does not invalidate processes previously shown to significantly alter social structures, economies and labour markets. Firstly, those related to the climate crisis, the decrease in various types of resources, sometimes crucial for the performance of the learned profession by a large group of inhabitants of a given territory (e.g., fishermen, when fishing grounds have been depleted). Secondly, those related to automation resulting in 
less demand for low-skilled jobs. A few years before the pandemic, it was realised that technological change was leading to a post-work society, where robotisation would not only support services, but would imply changes in various sectors of the economy (Srnicek \& Williams, 2015; PwC, 2018). David Graeber, the author of a brilliant essay on work in the $21^{\text {st }}$ century, attempted to prove how irrational the hypertrophy of some performed and paid activities is, supposing that it is in fact a way of hiding unemployment in the markets of developed countries (Graeber, 2018). Research relating to the future of work (the pace of change, the skills needed and the relocation of places) shows a thing that is not inconsiderable in the COVID-19 era. An offshoot of new technologies is the simultaneous elimination of jobs (displacement from the market of jobs based on personal interactions) and the creation of new ones (related to remote working). In light of these projections, by 2025 the time spent on current tasks at work by humans and machines will be equal (World Economic Forum, 2020, p. 5).

The COVID-19 pandemic can therefore be regarded as an unprecedented natural experiment. Not because there has never been a pandemic before, but because the affected societies this time have the opportunity to communicate with each other, and the globalised economy forms a system of interconnected vessels whose elements interact with each other. An experiment of this type does not allow researchers to manipulate variables, to introduce control variables. However, conducting observations cannot be completely random, in the maze of interesting phenomena we concentrate on selected variables, according to the research problem. The inability to control the observed processes determines the behaviour of researchers representing natural sciences differently from how it is determined in social sciences, with research focused on public policies (management within them). In the latter case, despite the unpredictability of the virus mutation, the course and consequences of the disease, researchers from different countries had to use conceptual categories referring to instruments previously used in analyses concerning the labour market. The sources of the analysis presented below are the various rapid assessments of the employment impacts of COVID-19. These are obtained and published by the International Labour Organisation, comprising, inter alia, a description of legal and financial decisions taken by governments between late spring and autumn 2020. The estimated global employment loss in 2020 is much greater than the previously projected "no pandemic", four times greater than in the aftermath of the 2009 crisis. The shutdown determining labour markets covered more than $80 \%$ of the 
world's population at its peak, 8.8 hours of work were lost, which translates into 255 million full-time jobs (ILO, 2021, p. 2).

The need for quick responses, the need to coordinate the cooperation of many actors and the lack of an unlimited pool of funds meant that interventions were not innovative. Environmental issues were hardly taken into account. The closure of production due to COVID-19 proved far more important than technological unemployment.

\section{CHALLENGES IN A TIME OF CRISIS}

The increase in the number of cases and the subsequent declaration of a pandemic by the WHO amounted to a crisis affecting society, public services, and the economy. The spread of the virus made it necessary to activate all crisis management mechanisms to protect the health and safety of the population. Whether or not a state of emergency was decided upon, the economy was affected by border closures, travel bans, bans on public gatherings, and sometimes a partial or total lockdown. Disruptions included trade, supply chains, tourism receipts, foreign investment, inhibited international aid money transfers and migrant remittances. New challenges emerged for labour market support institutions. Constraints forced companies to introduce measures to ensure the safety of their employees. Where possible, face-to-face contacts were replaced by teleworking, working hours were reduced, all or part of the staff were sent on leave. There were also layoffs of staff who were not essential, and finally staff reductions through redundancies due to a decline in production and turnover. In order to counteract these effects, governments designed legal and financial solutions addressed to companies, households and the most vulnerable categories of citizens.

Management in situations of this type is determined by the rapid identification of risks and assessment of the situation. A limitation is the ability to provide support adequate to current needs, organised by state authorities and managers in regional and local structures and specialised state agencies. In this case, support must address not only health issues, but also existential issues related to survival. It should include citizens, with particular attention to individuals from disadvantaged groups, and entrepreneurs. The latter are motivated to maintain jobs.

The consequences of decisions taken by governments to protect the health and lives of citizens are being diagnosed by state and non-governmental research 
centres. The International Labour Organisation prepared, in May 2020, guidelines to assess the relationship between the spread of the disease, decisions on partial or total closure and the economy and the labour market. It was postulated to take into account data on the national economy before the crisis, its global interconnections, distinguishing categories making it possible to characterise the period and the sectoral scope of lockdown, the decline in economic activity of various entities (ILO-4, 2020). Paying attention to threats to certain sectors, as a consequence of the decline in economic activity, allows us to estimate the primary and secondary effects of the lockdown - loss of jobs, increased unemployment and inactivity, changes in forms of employment, loss of income. The analysis of the reports confirms that the economic slump affected the wholesale and retail trade, catering, tourism and hotel industry, transport. The entertainment and exhibition industries, as well as services based on direct contact with customers, found themselves in an extremely difficult situation. The consequences are particularly acute for certain social groups: women, young people, people in pre-retirement age. The reports also contain data on the amount of resources committed by the state (in absolute numbers and as a percentage of the GDP) and a list of fields of state activity, instruments used to stop the economic recession and its negative consequences on the labour market.

By analysing these data, I am trying to answer the question of whether climatic and technological variables were taken into account in the design of protective measures, and what determines the possible originality of the adopted solutions. It would be interesting, however, beyond the scope of this type of study, to consider which non-economic factors inhibit and which stimulate government decisions on interventions to minimise the negative impact of the pandemic on the labour market ${ }^{1}$.

1 The analysis included reports from the following states: China, India, South Korea, Kyrgyzstan, Armenia, South Africa, Cameroon, Ethiopia, Lebanon, Argentina, Paraguay, Peru, Montenegro, Serbia, North Macedonia, Australia. 


\section{PERCEPTION OF CONSTRAINTS TO LABOUR MARKET INTERVENTION}

The correlation between the economic situation of each country before the pandemic and the labour market policy instruments that could be applied in the following months of 2020 is quite obvious. Their choice and effectiveness depended on the structure of the economy, its productivity and diversification. The pre-pandemic decline in the rate of growth of national income and the increasing public debt set limits to the governments' ability to act. The authors of the Asian country reports point to the dependence on the Chinese economy, whose slowdown has made a downturn likely. Relatively often, they cite the still unrecovered losses from the financial crisis of a decade ago. This context is also seen on the American continent. For the People's Republic of China, on the other hand, the experience of the SARS epidemic of 2003 was important. More specific indicators depicting the recession, concerning the suppression of production as well as exports and imports, are cited in concluding on such interdependencies. It was only in South Korea that the decline in international trade could be compensated for by exports of ICT-related items, which became necessary from 2020 for all workers switching to remote working and using hardware for education. Countries with a dominant agricultural sector and other sectors employing low-skilled labour did not have this opportunity. The expanded tourism sector, attractive in other circumstances, was becoming a "ball and chain" this time.

The capacities of countries to allocate and use resources also vary. On the one hand, these are issues of the amount of financial resources mobilised by governments, and on the other hand, qualitative strategies for fighting the crisis. Countries closer to the welfare state model have much more experience in shaping and implementing employment programmes, solving structural problems of the labour market and improving the functioning of businesses. Earlier investments in health care, basic infrastructure, research and development, education and computer software and hardware have paid off in times of crisis. Decisions about the duration of lockdown, the stages of closure and restarting various industries are of great importance for the labour market itself. There is an obvious feedback loop between the epidemiological situation and such decisions.

Job contraction is evident in some sectors. Keeping a job is about qualifications. The pandemic has reduced labour force participation, people are not working longer hours, they are not looking for extra jobs. There are a number of those 
who have lost their jobs. A skilled person can work below his or her capabilities or make an effort to retrain. The low-skilled working poor are at a disadvantage. Many businesses have been given the opportunity in the pandemic to suspend operations. In the classification used by employment services into unemployed and economically inactive people, there should be a third category, liminal, growing out of this suspension. We are dealing with people who are no longer workers and not yet unemployed. Women withdraw from the labour market (because of the need to care for children) or lose their jobs due to employment in various types of service sectors (hospitality, catering, trade, direct work with clients). The problem of women as a disadvantaged group on the labour market has appeared in every report.

Where possible, early retirement was facilitated for workers at an advanced age (South Korea). Young people, graduates of secondary and higher education, from virtually all countries, are in an extremely unfavourable situation. All the more so as the first employment of young workers is often of an informal nature. They also often perform simple jobs, with limited opportunities for telework. The pandemic has lowered the probability of finding a job and more people without work experience have found themselves on the market. It is difficult not to reflect on the accuracy of Ivan Krastev's statement that the generations debuting at work in the second and third decades of the $21^{\text {st }}$ century will probably spend most of their adult lives in conditions of catastrophic recession (Krastev, 2020, p. 45). Layoffs are also affecting those employed in education, mainly where a significant proportion of schools are private (Lebanon).

A frequently demonstrated problem is the existence of a growing category of informal workers who are not subject to the labour code, do not receive social benefits (social security, paid annual and sick leave) and are not represented and supported by trade unions (India, South Africa, Cameroon, Paraguay). Leaving aside the relationship between the non-observed economy and the state budget, instruments aimed at protecting jobs are not applicable in this case. Transition of workers to the formal sector is less and less possible.

Unemployment caused by the pandemic affects the urban population to a greater extent; work in the countryside, which is different in nature, can be carried out continuously. It is noticeable that internal migrants who have lost their jobs are returning to the countryside. There is no longer any paid work for them. Similar returns and forced idleness are experienced by those previously employed abroad, now forced repatriates. Foreigners hired to do domestic work are in a catastrophic situation, often losing both their income and their ability 
to return. The problem also concerns refugees residing in the territory without the right to work or social benefits.

As a significant limitation of the effectiveness of employment and labour market policies in the era of the pandemic, in addition to the stability/non-stability of state economy, the dominance of high-risk sectors (companies suspending operations for security reasons during the blockade and due to the profile of their activities), and the lack of institutionalised mechanisms of action in employment and labour market policies are indicated. Hence, many postulations refer to the necessity of standardising in the future the issues of insurance, labour code, strengthening of health and safety standards, effective conduct of inspections, etc. If, on the other hand, prior to the pandemic, programmes dedicated to different categories of the unemployed were implemented and active and passive instruments were used to achieve employment policy objectives, their expansion, strengthening or targeting additional groups of people is not problematic.

\section{LABOUR MARKET POLICY INSTRUMENTS USED OR DESIGNED BY COUNTRIES DURING THE COVID-19 PANDEMIC}

The instruments of the time of crisis are different from those used before the pandemic primarily because of the hierarchy of objectives and the degree of involvement of different state entities. It is of paramount importance to carry out actions stimulating the economy by means of an active fiscal policy, accommodative monetary policy and credit and financial support for specific sectors. Outlays and aid measures targeted at the health service are indisputable.

By far the largest number of solutions supported by the largest amount of resources was dedicated to entrepreneurs: 1 . to maintain jobs, 2 . to create jobs. The third type of solutions enabling employment remained within the competence of public employment services and communication and training agencies and platforms.

In the first case, these were usually time-limited pay subsidies. They could apply only to selected industries or categories of enterprises (small and mediumsized ones). There were also procedural and subjective restrictions related to the size of the enterprise or industry. They could be linked to a ban on redundancies during the period of receiving the subsidy or earlier participation in the unemployment insurance system. In Australia, in addition to entrepreneurs, non-profit organisations could apply for this type of support. Relatively frequent decisions 
concerned temporary remission or deferral of taxes (including property tax) and insurance premiums (unemployment, retirement, accident), and incidentally payment of rents. However, most often the entitlements were granted to businesses from the SME segment and the self-employed. The one-off (and unfortunately not very high) benefit granted to all citizens - consumers in Serbia - was of an experimental character, similar to the basic guaranteed income.

Employers could gain more rights to redeploy workers, reduce working hours, alter the pay and send them to compulsory leaves, as long as the company had a chance of surviving the crisis. There was a call for a rethink of the forms of leave taken by workers to care for children. Unconventional solutions were sometimes associated with the simplification of producer-consumer relations (e.g., the possibility to sell agricultural products or fish without intermediaries). Among the professional categories supported were also independent artists (Serbia).

Functional instruments towards maintaining and creating jobs consisted of special lending conditions. State authorities asked banks to change the terms of the loans, to extend the repayment period of existing loans or new ones, at no additional cost. This was particularly true for credit lines used precisely to cover the costs of pay, to boost working capital or for investment. Entrepreneurs already in debt could be given a moratorium on repayment of their loans. Proposals were made to reduce the cost of loans. In addition to loans for entrepreneurs, instruments helping to create jobs can be classified as informational and administrative. They mainly consist in facilitating business registration (digitisation of procedures), organising or subsidising training for new employees.

Job creation subsidies, where they existed, were selective. In China, this instrument was intended to find work in the most vulnerable provinces, in local units, to assist internal migrants. In China, there has been momentum in expanding the recruitment system for key enterprises (including those related to health care in times of pandemics). Public services in most countries began to promote flexible working, teleworking and to encourage the shift of street trading to the Internet in times of crisis. Entrepreneurs are encouraged to hire trainees and employees to become self-employed. Since people of retirement age often become self-employed, training is organised for them (South Korea).

Support in all three categories is based on broadening and increasing the flexibility of solutions. Employers are encouraged to find solutions for employees from disadvantaged groups and non-typical forms of employment. Much less frequent were initiatives to subsidise private companies increasing employment (e.g., Montenegro). Definitely, even in the form of a postulation, increasing 
employment in public services did not appear. In a few cases, it was decided to allocate budget funds for public works.

The speed of responding to the deteriorating labour market situation in the second and third quarters of 2020 was possible thanks to already existing institutions and employment and social assistance policy programmes. It was far easier for countries that had employment insurance in place, including pension or unemployment insurance. Others stressed the importance of formal employment in such circumstances. Monitoring compliance with labour market regulations for the future and initiating checks related to occupational health security were called for. In countries without extensive public employment policy interventions prior to the pandemic, simple measures - facilitating the registration of micro-enterprises, the obtaining of loans by such firms, on-line training - are of pioneering nature. It is important to support elementary mobility, transport to the workplace or support for job placement agencies. There is also a deficit of infrastructural solutions, communication systems between regional centres, IT platforms enabling remote working and web portals for jobseekers and employers, programmes allowing the monitoring, evaluation, and reporting on job placement.

\section{ADDRESSING THE CHALLENGES OF THE CLIMATE CRISIS AND THE TECHNOLOGICAL SHIFT TOWARDS A POST-WORK SOCIETY}

Concern for their own safety and that of their employees, together with all the forms of closure used, has accelerated the transition to teleworking wherever possible. This type of work has also benefited labour market and vocational training institutions and, in different time horizons, will facilitate the activities of the whole administration (e-government). The accelerated transformation of services (if we consider 2020) certainly brings cost savings, is rational from the point of view of health security and logistics but, unfortunately, it reveals numerous drawbacks related to employment. It may be used to dismiss less qualified workers or to reduce salaries. Public services implementing labour market policies are most often the providers of active and supply-oriented instruments. They undertake initiatives in the field of vocational guidance, further education and training. ICT companies and innovative projects were mentioned among the activities obtaining credit guarantees. 
Some of the initiated solutions require amendments to the law. In the analysed reports, there was a demand for preparation of changes in legislation and protection of employees' rights in new flexible forms of employment (China). Internet platforms for cooperation, using applications installed in phones, turned out to be extremely helpful during the pandemic in organising, for example, deliveries of meals or other types of transport. There is a growing demand to rethink their taxation and, more generally, to define such services in terms of work performed (Armenia).

In the presented employment stimulation programmes, measures and ways of action for economic recovery are mentioned, incidentally associated expressis verbis with climate risks and technological unemployment. The design of public works, where such decisions have been made, is an explicit response to environmental challenges and is designed to prevent the effects of climate change. For example, in South Africa, state funds will be used for work related to the protection of the natural landscape; in Armenia, public works will be carried out in mountainous areas at risk of flooding.

The instruments used during the pandemic did not have to compete with pro-innovation and pro-environmental projects, if such projects existed before. However, there is a concern that sustainability is a very "photogenic idea". It is certainly present in the reporting of labour market policy measures regardless of the region and technological sophistication of the economy (South Korea, Kyrgyzstan, Serbia, South Africa, Paraguay). It is less often illustrated with specific measures. For example, Korea's draft post-pandemic public policies include segments called the Green New Deal and the Digital New Deal. They aim to accelerate the transition to a digital and green economy. Firstly, by investing in ICT infrastructure, platforms and networks for collecting and integrating big data, developing artificial intelligence, and secondly, by supporting investments in energy and environmentally friendly industries. The project assumes the creation of 1.9 million jobs by 2025. This type of policy is less feasible in countries where the COVID-19 pandemic has exposed the failings of the economy, the extent of employment in the informal economy and the impotence of the state, including public employment services, to face the challenges of the $21^{\text {st }}$ century. 


\section{CONCLUSIONS}

Countries, regardless of the region, started 2020 with moderate optimism. Global employment increased, although the pay stagnated. Responsibility on many issues (health insurance, accident insurance and pensions) was left to the workers themselves. As the recession triggered by the COVID-19 pandemic began to determine economic processes, existing labour market policy instruments proved inadequate in many places. State authorities decided to adopt specific packages of solutions depending on the shape and condition of the economic system, diagnosed structural problems, resources which could possibly be used. They showed their intention to protect those social categories that are most threatened by unemployment as a consequence of the crisis. Despite the knowledge of environmental threats and polarisation of society resulting from the Fourth Industrial Revolution, remedial measures are extremely rarely found in the solution packages. This may be referred to as the Matthew Effect. Only a few countries with developed economies can afford to apply preventive measures. Comparative research is able to show among the implemented solutions ones that are original, related to national labour markets, and at the same time the invention of expert bodies and political decision-makers. The effectiveness of the applied instruments (depending on economic, social, epidemiological, legal and administrative factors) should be monitored and evaluated from a local, regional and supra-regional perspective. It would be interesting to correlate this effectiveness with the Human Capital Index.

\section{REFERENCES:}

Graeber, D. (2018). Bullshit Jobs: A Theory. New York: Simon and Schuster.

ILO-1 (2020, April 30). Containing the Epidemic and Its Impact on Jobs and Incomes in Ethiopia: Rapid Assessment and Response Plan. Retrieved from: https://www. ilo.org/wcmsp5/groups/public/---africa/---ro-abidjan/documents/briefingnote/ wcms_747012.pdf.

ILO-2 (2020, May 15). COVID-19 and the World of Work: Rapid Assessment of the Employment Impacts and Policy Responses. NORTH MACEDONIA. Retrieved from: https://www.ilo.org/wcmsp5/groups/public/---europe/---ro-geneva/---srobudapest/documents/publication/wcms_746124.pdf.

ILO-3 (2020, May 25). Chacaltana, J. Rapid Response to COVID-19 under High Informality? The Case of Peru. Retrieved from: https://www.ilo.org/wcmsp5/groups/ public/---ed_emp/documents/publication/wcms_746116.pdf. 
ILO-4 (2020, May). Rapid Diagnostics for Assessing the Country Level Impact of COVID19 on the Economy and Labour Market: Guidelines. Retrieved from: https://www.ilo. org/wcmsp5/groups/public/---ed_emp/documents/publication/wcms_743644.pdf.

ILO-5 (2020, June 8). COVID-19 and the World of Work: Rapid Assessment of the Employment Impacts and Policy Responses. MONTENEGRO. Retrieved from: https:// www.ilo.org/wcmsp5/groups/public/---europe/---ro-geneva/---sro-budapest/documents/publication/wcms_749201.pdf.

ILO-6 (2020, June). Rapid Assessment of the Impact of the COVID-19 Crisis on Employment: India. Retrieved from: https://www.ilo.org/wcmsp5/groups/public/---asia/--ro-bangkok/---sro-new_delhi/documents/publication/wcms_748095.pdf.

ILO-7 (2020, July). China - Rapid Assessment of the Impact of COVID-19 on Employment. Retrieved from: https://www.ilo.org/wcmsp5/groups/public/---ed_emp/ documents/publication/wcms_752056.pdf.

ILO-8 (2020, August). Ernst, Ch., \& López Mourelo, E. COVID-19 and the Labour Market in Argentina. Retrieved from: https://www.ilo.org/wcmsp5/groups/public/--ed_emp/documents/publication/wcms_754689.pdf.

ILO-9 (2020, August). Rapid Diagnostic Assessment of Employment Impacts under COVID-19 in Lebanon. Retrieved from: https://www.ilo.org/wcmsp5/groups/ public/---ed_emp/documents/publication/wcms_754666.pdf.

ILO-10 (2020, August). Strauss, I., Isaacs, G., Rosenberg, J., Passoni, P. Rapid Country Assessment: South Africa. The Impacts from a COVID-19 Shock to South Africa's Economy and Labour Market. Retrieved from: https://www.ilo.org/wcmsp5/groups/ public/---ed_emp/documents/publication/wcms_754443.pdf.

ILO-11 (2020, September 1). COVID-19 and the World of Work: Rapid Assessment of the Employment Impacts and Policy Responses. SERBIA. Retrieved from: https:// www.ilo.org/wcmsp5/groups/public/---europe/---ro-geneva/---sro-budapest/ documents/publication/wcms_754624.pdf.

ILO-12 (2020, October). Rapid Assessment of the Employment Impact and Policy Responses of the COVID-19 Pandemic on Armenia. Retrieved from: https://www. ilo.org/wcmsp5/groups/public/---europe/---ro-geneva/---sro-moscow/documents/ publication/wcms_762029.pdf.

ILO-13 (2020, October). Rapid Assessment of the Employment Impacts of the COVID19 Pandemic in Kyrgyzstan. Retrieved from: https://www.ilo.org/wcmsp5/ groups/public/---europe/---ro-geneva/---sro-moscow/documents/publication/ wcms_761673.pdf.

ILO-14 (2020, November). Republic of Korea: A Rapid Assessment of the Employment Impacts of COVID-19. Retrieved from: https://www.ilo.org/wcmsp5/groups/public/--ed_emp/documents/publication/wcms_760063.pdf.

ILO-15 (2020, December). Cameroon - Rapid Evaluation of the Impact of COVID-19 on Employment and the Labour Market in Cameroon. Retrieved from: https://www.ilo. org/wcmsp5/groups/public/---ed_emp/documents/publication/wcms_763830.pdf. ILO-16 (2020, December). Reinecke, G., Montt, G., Cunego, A., Herken, V., Ocampos, A., \& Valfredi, P. Paraguay: Impacts of COVID-19 on Employment and Income Gen- 
eration. Retrieved from: https://www.ilo.org/wcmsp5/groups/public/---ed_emp/ documents/publication/wcms_763228.pdf.

ILO (2021, January 25). ILO Monitor: COVID-19 and the World of Work. Seventh Edition. Updated Estimates and Analysis. Retrieved from: https://www.ilo.org/wcmsp5/ groups/public/---dgreports/---dcomm/documents/briefingnote/wcms_767028.pdf.

Krastev, I. (2020). Nadeszło jutro. Jak pandemia zmienia Europę. Warszawa: Wydawnictwo Krytyki Politycznej.

OECD (2020, November 23). Job Creation and Local Economic Development 2020: Rebuilding Better. Paris: OECD Publishing. DOI: 10.1787/b02b2f39-en.

PwC (2018). J. Hawksworth, R. Berriman, S. Goel. Will Robots Really Steal Our Jobs? An International Analysis of the Potential Long Term Impact of Automation. Retrieved from: https://www.pwc.com/gx/en/news-room/docs/will-robots-really-steal-ourjobs-an-international-analysis-of-the-potential-long-term-impact-of-automation. pdf.

Srnicek, N., \& Williams, A. (2015). Inventing the Future: Postcapitalism and a World without Work. London-New York: Verso.

Taleb, N.N. (2010). The Black Swan: The Impact of the Highly Improbable (2 ${ }^{\text {nd }}$ Ed.). New York: Random House Publishing Group.

World Economic Forum (2020, October). The Future of Jobs Report 2020. Cologny/ Geneva: World Economic Forum. Retrieved from: http://www3.weforum.org/docs/ WEF_Future_of_Jobs_2020.pdf. 